\title{
Analisis Respons Hidrologi untuk Mendukung Perencanaan Pengelolaan Sub-DAS Opak Hulu, Daerah Istimewa Yogyakarta
}

\section{(Analysis of Hydrological Response to Support Management Planning for Opak Hulu Watershed, Daerah Istimewa Yogyakarta)}

\author{
Nicko Widiatmoko ${ }^{1 *}$, Suria Darma Tarigan², Enni Dwi Wahjunie ${ }^{2}$
}

(Diterima September 2019/Disetujui Juni 2020)

\begin{abstract}
ABSTRAK
Salah satu penyebab penurunan fungsi hidrologis adalah perubahan penggunaan lahan yang berpengaruh pada respons hidrologi suatu daerah aliran sungai (DAS). Perencanaan pengelolaan DAS perlu dilakukan untuk memperbaiki fungsi hidrologis DAS tersebut. Penelitian ini bertujuan untuk mempelajari respons hidrologi dalam mendukung perencanaan pengelolaan DAS di Sub-DAS Opak Hulu. Penelitian ini dilakukan dengan menggunakan pemodelan hidrologi Soil and Water Assessment Tool (SWAT). Metode yang digunakan meliputi pengumpulan data, pengolahan data input, penggunaan model SWAT, kalibrasi, validasi, dan skenario pengelolaan DAS terbaik. Hasil analisis perubahan penggunaan lahan sub-DAS Opak Hulu pada tahun 2012-2017 mengalami peningkatan signifikan pada pertanian lahan kering campur $(3,21 \%)$ dan semak belukar $(1,43 \%)$. Penggunaan lahan menurun signifikan, yaitu tanah terbuka sebesar 2,31\% dan pertanian lahan kering sebesar 1,71\%. Berdasarkan skenario karateristik hidrologi yang dianalisis, teknik konservasi tanah dan air (KTA) mampu menurunkan aliran permukaan serta meningkatkan aliran lateral dan aliran dasar. Skenario tersebut mampu menurunkan aliran permukaan sebesar $542,22 \mathrm{~mm}(27,09 \%)$ serta menaikkan aliran lateral sebesar $321,82 \mathrm{~mm}(13,15 \%)$, dan aliran dasar sebesar $797,28 \mathrm{~mm}(18,32 \%)$. Perencanaan pengelolaan DAS terbaik dengan teknik KTA mampu menghasilkan nilai KAT 0,33 (sedang) dan KRA 69,85 (sedang).
\end{abstract}

Kata kunci: DAS, model SWAT, penggunaan lahan, teknik konservasi tanah dan air

\section{ABSTRACT}

Land use change is one of the causes of the decreasing of hydrological function that affects the hydrological response of a watershed. Planning of watershed management needs to be conducted to improve the hydrological function of the watershed. This study aims to determine the hydrological response in supporting watershed management planning in Opak Hulu Watershed. This research was conducted using the Soil and Water Assessment Tool (SWAT) hydrological modeling. The method used included data collection, processing of input data, running of SWAT model, calibration, validation, and the decision of the best watershed management scenarios. The results of the analysis of land use changes in the Opak Hulu Watershed in 2012-2017 had a significant increase in mixed upland agriculture (3.21\%) and shrubs (1.43\%). Meanwhile, open field $(2,31 \%)$ and dry land agriculture $(1.71 \%)$ decreased significantly. Based on the analyzed hydrological scenario, Soil and Water Conservation techniques can decrease the surface runoff and increase the lateral flow and base flow. The scenario is able to decrease the surface runoff by $542.22 \mathrm{~mm}(27.09 \%)$. It increases lateral flow and base flow by $321.82 \mathrm{~mm}(13.15 \%)$ and $797.28 \mathrm{~mm}(18.32 \%)$, respectively. The best watershed management planning with Soil and Water Conservation technique is able to reach Annual Flow Coefficient value to 0,33 (moderate) and 69,85 (moderate) for Flow Regime Coefficient.

Keywords: land use, soil and water conservation techniques, SWAT model, watershed

\section{PENDAHULUAN}

Daerah aliran sungai (DAS) adalah sebuah kawasan yang dibatasi oleh pemisah topografis, yang menyimpan, menampung, dan mengalirkan air curah

1 Sekolah Pascasarjana,Fakultas Pertanian, Institut Pertanian Bogor, Kampus IPB Darmaga, Bogor 16680

2 Departemen Ilmu Tanah dan Sumberdaya Lahan, Fakultas Pertanian, Institut Pertanian Bogor, Kampus IPB Darmaga, Bogor 16680

* Penulis Korespondensi:

Email: nicko.widiatmoko@gmail.com hujan yang jatuh di atasnya ke sungai utama yang bermuara ke laut atau danau (Manan 1979). Pengelolaan DAS yang baik mampu mengurangi atau menghilangkan dampak-dampak negatif bagi lingkungan maupun bagi aktivitas yang terjadi di dalamnya dan dapat memberikan peningkatan kesejahteraan bagi masyarakat di sekitarnya (Arsyad 2010). PengeIolaan DAS pada dasarnya merupakan pengelolaan sumber daya alam yang bertujuan untuk memperbaiki, memelihara, dan melindungi kondisi DAS agar dapat menghasilkan barang dan jasa, khususnya kuantitas, kualitas, dan kontinuitas air (water yield) untuk berbagai kepentingan (Nuryanto et al. 2003). 
Sub-DAS Opak Hulu merupakan bagian dari DAS Opak-Oyo yang berada di Provinsi Daerah Istimewa Yogyakarta. Kota tersebut mengalami pertumbuhan dan perkembangan yang sangat cepat. Perkembangan kota tersebut berpengaruh pada daerah di sekitarnya sehingga mendorong perubahan penggunaan lahan daerah dan tentunya berpengaruh pada Sub-DAS Opak Hulu. Pertumbuhan penduduk menurut kabupaten/kota di Yogyakarta mengalami peningkatan, yaitu pada tahun 2015 sebesar 3.679.176.000 jiwa dan tahun 2018 sebesar 3.818.266.000 jiwa (BPS DIY 2019). Hasil inventarisasi lahan kritis yang dilakukan oleh Balai Pengelolaan DAS Serayu Opak Progo pada tahun 2004 diketahui bahwa sebagian besar DAS-DAS di wilayah Sungai Progo-Opak-Serang temasuk salah satu DAS Prioritas I (DAS sangat kritis) yang perlu segera dilakukan upaya kegiatan konservasi dalam rangka untuk mengembalikan fungsi lahan.

Laporan Kinerja BPDAS-HL SOP pada DAS Opak menunjukkan bahwa nilai KRA DAS Opak mengalamai peningkatan pada tahun 2013 sebesar 19,16; pada tahun 2014 sebesar 21,28; dan pada tahun 2015 sebesar 58,64 (BPDAS-HL SOP 2016). Nilai debit tahunan pada DAS Opak mengalami perubahan pada tahun 2012 hingga tahun 2015 berdasarkan Laporan Kinerja BPDAS-HL Serayu-Opak-Progo, yaitu pada tahun 2012 sebesar $53.839 .904 \mathrm{~m}^{3} /$ tahun dan pada tahun 2015 meningkat sebesar $76.950 .432 \mathrm{~m}^{3} /$ tahun.

Penggunaan lahan yang mendominasi DAS Opak adalah pertanian, yaitu sekitar 41,362 ha atau $30,21 \%$ dan permukiman sekitar 41,063 ha atau $29,97 \%$ dari total luas DAS (BPDAS SOP 2018). Perubahan hutan di wilayah DAS menjadi penggunaan lainnya berdampak negatif pada karakteristik hidrologi. Perubahan penggunaan lahan yang terjadi di daerah hulu DAS dipastikan akan mengakibatkan perubahan karakterisitik hidrologi DAS (Pawitan 2006). Pengawasan perubahan penggunaan lahan terhadap respons hidrologi perlu dilakukan melalui kajian. Kajian dapat dilakukan secara langsung dengan melakukan evaluasi dan berbagai pengukuran di lapangan atau memprediksinya dengan menggunakan model (Rachman \& Dariah 2007).

Model Soil and Water Assessment Tool (SWAT) merupakan salah satu model hidrologi yang dikembangkan untuk memprediksi pengaruh pengelolaan lahan pada hasil air, sedimen, muatan pestisida, dan kimia hasil pertanian yang masuk ke sungai/badan air pada suatu DAS yang kompleks (Neitsch et al. 2005). Menurut Junaidi \& Tarigan (2012), penggunaan model hidrologi SWAT merupakan alternatif dalam menentukan kondisi perencanaan pengelolaan DAS terbaik. SWAT merupakan model hidrologi yang banyak digunakan untuk mengevaluasi dampak iklim, penggunaan lahan, dan pengelolaan lahan pada karakteristik hidrologi (Arnold et al. 2011). Penelitian ini bertujuan untuk mengetahui respons hidrologi berdasarkan karateristik hidrologi dalam mendukung perencanaan pengelolaan Sub-DAS Opak Hulu, Provinsi Daerah Istimewa Yogyakarta.

\section{METODE PENELITIAN}

\section{Waktu dan Lokasi Penelitian}

Penelitian dilaksanakan pada Januari-Juli 2019 pada lokasi penelitian Sub-DAS Opak Hulu, D.I.Yogyakarta. Sub-Das Opak hulu terletak pada Kabupaten Sleman dan Bantul pada Provinsi D.I.Y dan Kabupaten Klaten pada Provinsi Jawa Tengah. Luas Sub-DAS Opak Hulu adalah 14.679,18 ha. DAS Opak yang berada di Provinsi Daerah Istimewa Yogyakarta dan panjang sungai utama adalah $\pm 65 \mathrm{~km}$. Sungai Opak mempunyai beberapa anak sungai utama dan cukup penting untuk keseimbangan alam di Provinsi Daerah Istimewa Yogyakarta, yaitu Kali Gajahwong, Kali Code, Kali Winongo, Kali Kuning, Kali Belik, Kali Tambakbayan, dan Kali Gendol (PSDA Progo-OpakSerang 2010). Lokasi Sub-DAS Opak Hulu disajikan pada Gambar 1.

Sub-DAS Opak bagian hulu di dalamnya terdapat dua sungai besar, yaitu Sungai Opak dan Gendol yang masuk ke dalam sistem DAS Opak. Batas Sub-DAS tersebut dibuat berdasarkan SK. Menhut. Nomor SK.511/Menhut-V/2011. Secara umum, area kajian berada di lereng selatan Gunung Merapi dari puncak sampai pertemuan antara Sungai Opak dan Gendol.

\section{Alat, Bahan, dan Jenis Data}

Alat yang digunakan dalam penelitian adalah peralatan survei lapangan (pengambilan sampel tanah) dan ring permeabilitas, seperangkat komputer, ArcGis 10.1, ArcSWAT versi tahun 2012, Microsoft office 2016, global positioning sistem (GPS), peta dan data pendukung untuk analisis SWAT dan GIS, kamera, ATK, serta alat lainnya yang diperlukan selama penelitian. Data yang digunakan ialah data iklim, data debit, data curah hujan, peta penggunaan lahan pada tahun 2012 dan 2017, data DEM, data tanah, Peta RTk-RHL, dan Peta RTRW.

\section{Analisis Perubahan Penggunaan Lahan}

Analisis perubahan penggunaan lahan pada software ArcGIS 10.1 dilakukan dengan cara mengoverlay peta penggunaan lahan Sub-DAS Opak Hulu pada tahun 2012 dan peta penggunaan lahan pada tahun 2017 sehingga menghasilkan informasi perubahan penggunaan lahan secara spasial dan temporal. Hasil overlay tersebut digunakan untuk mengetahui luas lahan di Sub-DAS Opak Hulu dengan membandingkan tren perubahan penggunaan lahan pada tahun 2012 dan 2017. Tahapan penelitian meliputi input, proses, dan output yang disajikan pada diagram alir penelitian (Gambar 2). 


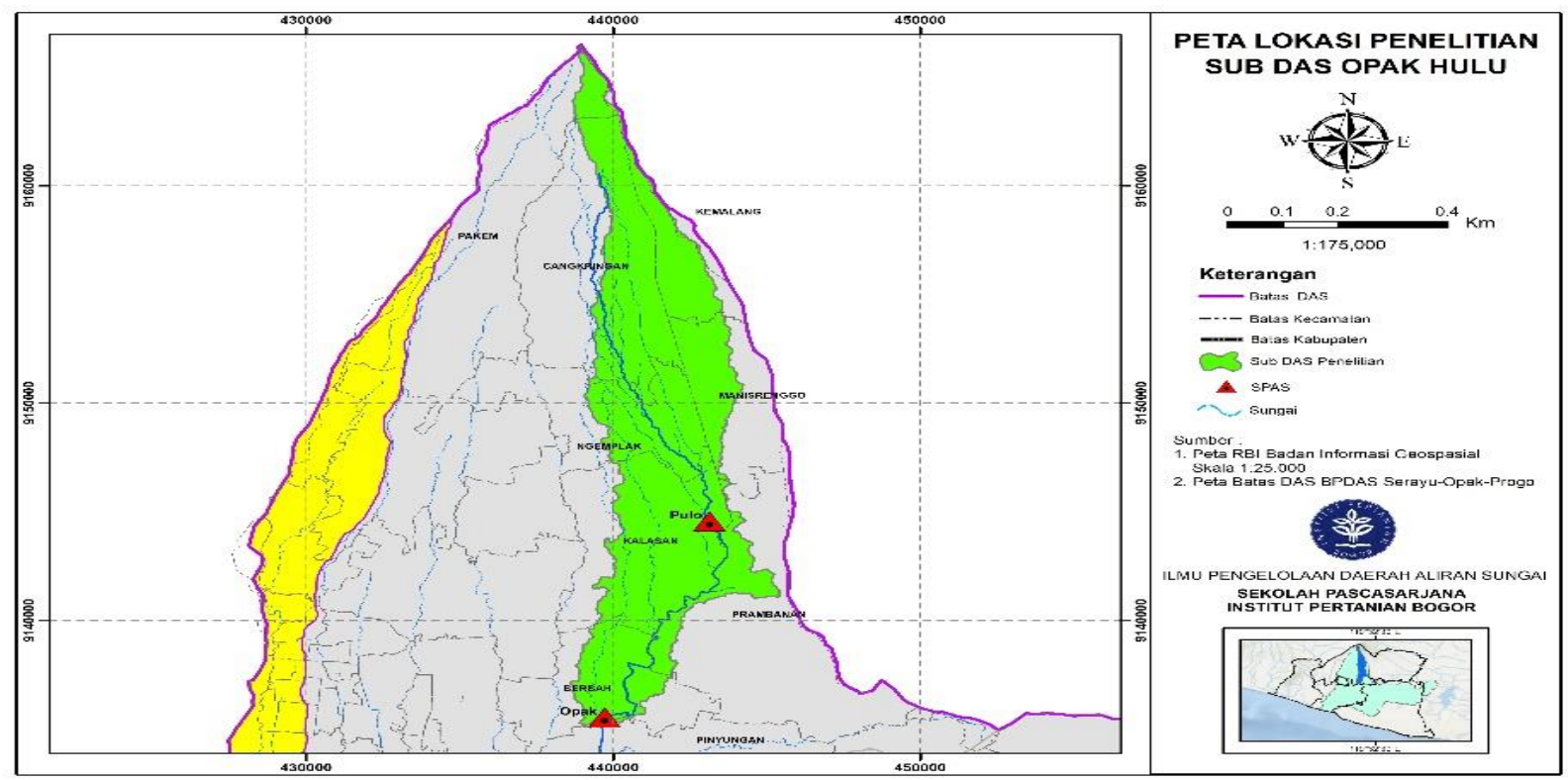

Gambar 1 Lokasi penelitian Sub-DAS Opak Hulu (BPDAS SOP).

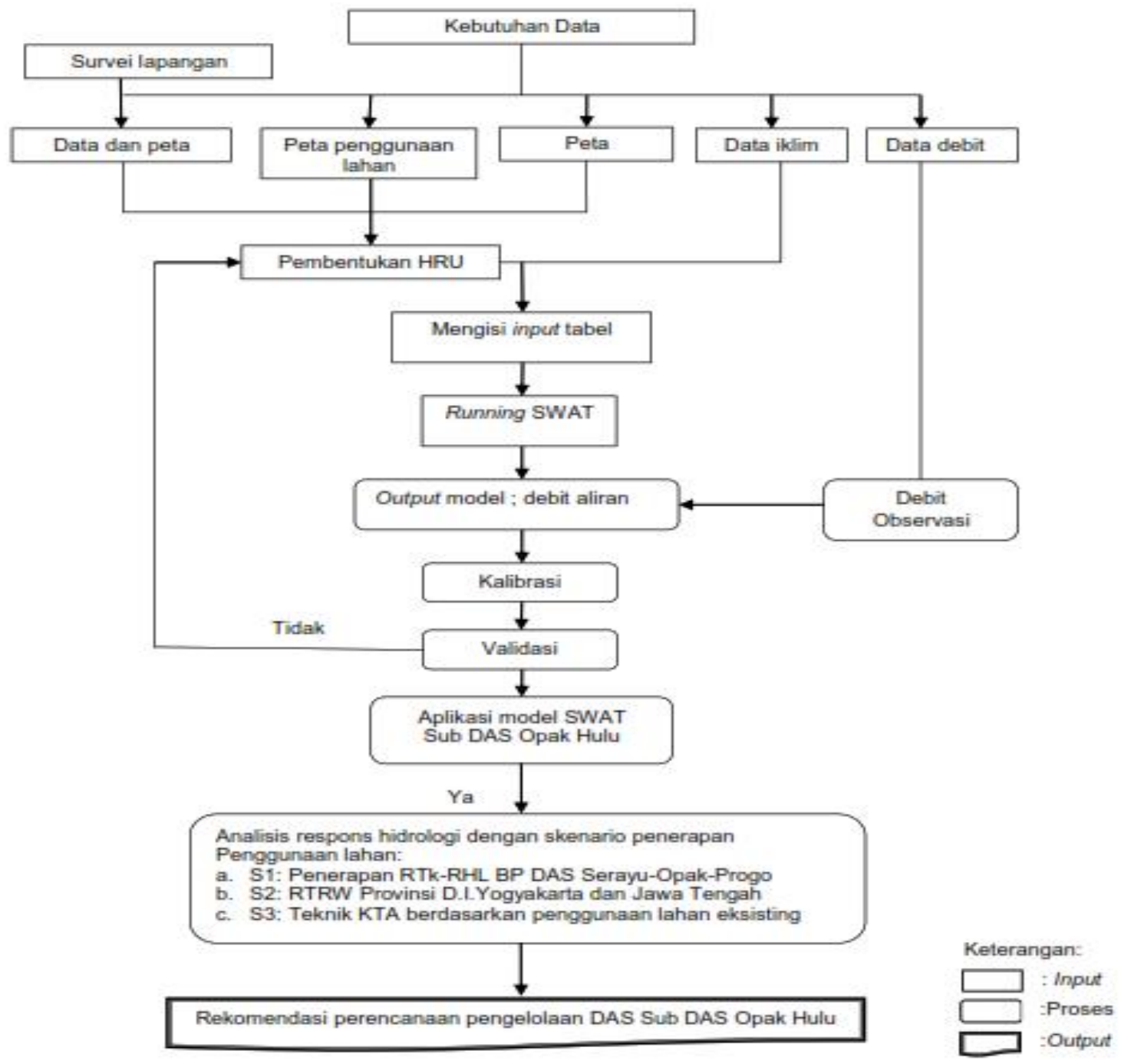

Gambar 2 Diagram alir penelitian. 


\section{Analisis Data dengan Model SWAT}

Analisis data menggunakan model SWAT yang disesuaikan dengan tujuan penelitian yang meliputi pengolahan data masukan (input) berupa data tanah, data penggunaan lahan, data DEM (Digital Elevation Model), data curah hujan, data iklim, dan data debit. Deliniasi DAS meliputi pemasukan data DEM grid (add $D E M$ grid), penentuan jaringan sungai (stream definition), penentuan outlet (outlet definition), seleksi dan penentuan outlet DAS (watershed outlet selection and definition), dan penghitungan parameter Sub-DAS (calculate subbasin parameter). Langkah selanjutnya dalam menjalankan SWAT ialah pembentukan HRU (Hidrological Responsse Unit), input data iklim, pembangunan data masukan model, dan running SWAT.

\section{Kalibrasi}

Kalibrasi model dilakukan dengan cara memilih nilai-nilai untuk input parameter model secara hati-hati dengan membandingkan data prediksi model (output) untuk satu set kondisi yang diasumsikan dengan data observasi untuk kondisi yang sama (Arnold et al 2012). Kalibrasi dalam model SWAT dilakukan dengan menyesuaikan kombinasi nilai parameter yang berpengaruh pada kondisi hidrologi DAS sehingga diperoleh hasil model (debit model) yang mendekati hasil pengukuran (debit observasi). Data debit yang digunakan dalam proses kalibrasi adalah data debit harian selama bulan Januari-Desember 2017.

Ketelitian dan ketepatan hasil ouput model diuji dengan menggunakan metode statistik, yaitu koefisien determinasi $\left(\mathrm{R}^{2}\right)$ dan Nash-Sutcliffe Efficiency (NSE). Koefisien determinasi adalah nilai kuadrat dari koefisien korelasi berdasarkan Bravais-Pearson. Menurut Silva et al (2015), nilai 0,4 $<$ NSE $<0,5$ pada model SWAT dapat diterima dan digunakan untuk mensimulasi debit aliran di suatu DAS sehingga model yang dibangun dapat mensimulasikan skenario yang diinginkan.

Penggunaan persamaan model efisiensi NashSutcliffe Efficiency (NSE) direkomendasikan oleh The American Society of Civil Engineers dalam menguji keakuratan output model. Persamaannya adalah sebagai berikut:

$$
\mathrm{NSE}=1-\left[\frac{\sum_{i=1}^{n}\left(Y_{i}^{o b s}-Y_{i}^{s i m}\right)^{2}}{\sum_{i=1}^{n}\left(Y_{i}^{o b s}-\bar{Y}^{o b s}\right)^{2}}\right]
$$

Keterangan:

$Y_{i}{ }^{o b s}=$ Data observasi ke- $\mathrm{i}$

$Y_{i}{ }^{\text {sim }}=$ Data simulasi ke-i

$\bar{Y}^{o b s}=$ Data observasi rata-rata

$n \quad=$ Jumlah observasi

Nilai efisiensi NSE dikelompokkan menjadi 4 kelas yang terdapat dalam Tabel 1 (Moriasi et al. 2007).

\section{Validasi}

Validasi bertujuan untuk membuktikan konsistensi hasil suatu model yang diujikan pada periode yang lain. Nilai parameter yang digunakan dalam proses validasi sama dengan nilai parameter pada proses kalibrasi. Proses selanjutnya adalah membandingkan data hasil simulasi dan data observasi pada periode yang berbeda. Validasi dilakukan dengan menjalankan model menggunakan parameter yang telah ditentukan selama proses kalibrasi, dan membandingkan data debit yang sudah dikalibrasi dengan data debit pengukuran pada periode lain.

Metode statistik yang digunakan dalam melakukan validasi adalah model koefisien determinasi $\left(R^{2}\right)$ dan model efisiensi Nash-Sutcliffe Efficiency (NSE) dengan kriteria yang sama seperti yang digunakan dalam proses kalibrasi. Variabel yang diuji dalam penelitian ini adalah debit aliran. Data debit yang digunakan pada proses validasi adalah data debit periode harian selama bulan Januari-Desember 2016.

\section{Analisis Kondisi DAS Berdasarkan Karakteristik Hidrologi}

Kondisi DAS secara umum dapat dianalisis dari debit aliran sungai. Analisis kondisi DAS berdasarkan debit dinyatakan dalam koefisien regim sungai (KRS) dan koefisien aliran permukaan (C). Berdasarkan Direktorat Jenderal (Dirjen) Rehabilitasi Lahan dan Perhutanan Sosial (RLPS), istilah lain untuk koefisien regim sungai adalah Koefisien Regim Aliran (KRA=KRS) dan koefisien aliran permukaan adalah Koefisien Aliran Tahunan (KAT=C).

Koefisien runoff (koefisien aliran permukaan) merupakan perbandingan nilai direct runoff $(\mathrm{mm})$ dengan nilai curah hujan $(\mathrm{mm})$. Oleh karena itu, output simulasi model SWAT pada kondisi eksisting, nilai C skenario 1, 2, dan 3 dihitung. Koefisien Rezim Sungai (KRS) dapat digunakan untuk mengetahui kuantitas aliran sungai dari waktu ke waktu, khususnya nilai nisbah debit maksimum pada musim hujan dan minimum pada musim kemarau. Klasifikasi nilai KAT (C) dibagi menjadi 5 kategori (Tabel 2).

Koefisien Regim Aliran (KRA) merupakan nisbah antara debit maksimum (Qmax) dan debit minimum (Qmin) tahunan. Klasifikasi nilai KRA ini ditentukan berdasarkan klasifikasi Dirjen RLPS sebagaimana tercantum dalam Peraturan Menteri Kehutanan Republik Indonesia No: P. 61/Menhut-II/2014 yang disajikan pada Tabel 3.

Tabel 1 Kategori nilai efisiensi model dengan Nash-Sutcliffe Efficiency (NSE)

\begin{tabular}{cl}
\hline Nilai NSE & \multicolumn{1}{c}{ Kategori } \\
\hline $0,75<\mathrm{NSE} \leq 1,00$ & Sangat baik \\
$0,65<\mathrm{NSE} \leq 0,75$ & Baik \\
$0,50<\mathrm{NSE} \leq 0,65$ & Memuaskan \\
NSE $\leq 0,50$ & Kurang memuaskan \\
\hline Sumber: (Moriasi et al. 2007 dalam Chaube et al. 2011)
\end{tabular}




\section{Skenario Perencanaan Pengelolaan DAS Terbaik} - Skenario 1: penerapan pengelolaan penggunaan lahan RTK RHL BPDAS

Skenario ini diterapkan berdasarkan dokumen Rencana Teknik Rehabilitasi Hutan dan Lahan (RTk $\mathrm{RHL}$ ) DAS yang disusun oleh Balai Pengelolaan DAS Serayu-Opak-Progo. Peta penggunaan lahan yang dipakai dalam analisis model merupakan hasil tumpang susun (overlay) antara peta penggunaan lahan eksisting dengan peta RTk-RHL pada tahun 2015-2029. Tujuan overlay peta ini adalah untuk mendapatkan atribut peta yang lengkap, yang mana penggunaan lahan yang tidak tercakup dalam peta RTk-RHL, namun masih dalam batas DAS, akan diisi oleh penggunaan lahan eksisting.

Simulasi pada skenario ini dilakukan dengan melakukan overlay antara peta sub-basin hasil SWAT dengan peta RTk-RHL sehingga diketahui sub-DAS mana saja yang ada kegiatan RHL-nya. Parameter hidrologi SWAT yang diterapkan di antaranya adalah CN2 (bilangan kurva aliran permukaan).

- Skenario 2: Penerapan RT/RW Provinsi Daerah Istimewa Yogyakarta dan Jawa Tengah pada penggunaan lahan eksisisting (2017)

Skenario ini diterapkan berdasarkan pola ruang pada Peta RTRW Provinsi D.I.Yogyakarta dan Jawa Tengah pada tahun 2012-2032 pada penggunaan lahan eksisting tahun 2017. Peta RTRW merupakan arah kebijakan tata ruang yang sifatnya menyeluruh

Tabel 2 Klasifikasi koefisien runoff

\begin{tabular}{ll}
\hline \multicolumn{1}{c}{ Nilai } & \multicolumn{1}{c}{ Kelas } \\
\hline $\mathrm{C}<0,2$ & Sangat rendah \\
$0,2<\mathrm{C} \leq 0,3$ & Rendah \\
$0,3<\mathrm{C} \leq 0,4$ & Sedang \\
$0,4<\mathrm{C} \leq 0,5$ & Tinggi \\
$\mathrm{C}>0,5$ & Sangat tinggi \\
\hline
\end{tabular}

Sumber: (Permenhut 61 tahun 14).

Tabel 3 Klasifikasi koefisien rezim sungai

\begin{tabular}{ll}
\hline \multicolumn{1}{c}{ Nilai } & \multicolumn{1}{c}{ Kelas } \\
\hline KRA $<20$ & Sangat rendah \\
$20<$ KRA $\leq 50$ & Rendah \\
$50<$ KRA $\leq 80$ & Sedang \\
$80<$ KRA $\leq 110$ & Tinggi \\
KRA $>110$ & Sangat tinggi \\
\hline
\end{tabular}

Sumber: (Permenhut 61 tahun 14). dan mengatur arahan pengembangan pusat-pusat kegiatan di suatu wilayah. Berdasarkan peta RTRW Provinsi D.I.Yogyakarta dan Jawa Tengah, penggunaan Iahan Sub-DAS Opak Hulu terdiri atas kawasan hutan dan nonhutan. Penerapan nilai CN2 hanya pada kawasan nonhutan resapan air, untuk penggunaan lahan nonhutan lainnya disesuaikan dengan penggunaan lahan existing.

\section{- Skenario 3: penerapan teknik KTA berdasarkan penggunaan lahan eksisting (2017)}

Penerapan teknik KTA berdasarkan skenario disesuaikan dengan kondisi lereng maupun penggunaan lahan eksistingnya. Teknik KTA yang diterapkan pada sub-DAS tersebut adalah teknik KTA secara metode vegetatif berupa agroforestry, seperti pada areal pertanian lahan kering, pertanian lahan kering campur, dan semak. Penerapan teknik KTA secara mekanik adalah countouring dan sumur resapan, sedangkan pada hutan lahan sekunder dan hutan tanaman pada kemiringan $>40 \%$ diterapkan reboisasi. Simulasi parameter SWAT yang diterapkan di antaranya adalah CN2 (nilai kurva aliran permukaan) berdasarkan USDA-NRCS (2004) dan Williams et al (1990) dalam Wang et al (2011).

\section{HASIL DAN PEMBAHASAN}

\section{Analisis Perubahan Penggunaan Lahan}

Penggunaan lahan secara umum dipengaruhi oleh dua faktor utama, yaitu faktor alami seperti iklim, topografi, tanah atau bencana alam dan faktor manusia berupa aktivitas manusia pada sebidang lahan. Faktor manusia dirasakan berpengaruh lebih dominan dibandingkan dengan faktor alam karena sebagian besar perubahan penggunaan lahan disebabkan oleh aktivitas manusia dalam memenuhi kebutuhannya pada sebidang lahan yang spesifik (Vink dalam Sudadi et al. 1991).

Selama periode tahun 2012-2017, seperti yang disajikan pada Tabel 4, terjadi peningkatan penggunaan lahan hutan, permukiman, pertanian lahan kering campur, dan semak belukar masing-masing sebesar 1,54 ha $(0,01 \%), 125,65$ ha $(0,85 \%), 470,67$ ha $(3,21$ ha), dan 210,57 ha $(1,43 \%)$. Penurunan terjadi pada hutan tanaman, pertanian lahan kering, sawah,

Tabel 4 Perubahan penggunaan lahan Sub-DAS Opak Hulu tahun 2012 dan 2017

\begin{tabular}{|c|c|c|c|c|c|c|}
\hline \multirow{2}{*}{ Penggunaan lahan } & \multicolumn{2}{|c|}{2012} & \multicolumn{2}{|c|}{2017} & \multicolumn{2}{|c|}{ Perubahan } \\
\hline & (ha) & (\%) & (ha) & (\%) & (ha) & $(\%)$ \\
\hline Hutan lahan kering sekunder & 117,20 & 0,80 & 118,73 & 0,81 & 1,54 & 0,01 \\
\hline Hutan tanaman & 813,57 & 5,54 & 812,04 & 5,53 & $-1,54$ & $-0,01$ \\
\hline Permukiman & 5021,47 & 34,21 & 5147,12 & 35,06 & 125,65 & 0,86 \\
\hline Pertanian lahan kering & 1099,94 & 7,49 & 849,13 & 5,78 & $-250,81$ & $-1,71$ \\
\hline Pertanian lahan kering campur & 548,91 & 3,74 & 1019,58 & 6,95 & 470,67 & 3,21 \\
\hline Sawah & 6227,96 & 42,43 & 6010,81 & 40,95 & $-217,16$ & $-1,48$ \\
\hline Semak/belukar & 0,00 & 0,00 & 210,57 & 1,43 & 210,57 & 1,43 \\
\hline Tanah terbuka & 850,13 & 5,79 & 511,21 & 3,48 & $-338,92$ & $-2,31$ \\
\hline Total & 14679,18 & 100 & 14679,18 & 100 & 0,00 & 0,00 \\
\hline
\end{tabular}


dan tanah terbuka masing-masing sebesar 1,54 ha $(0,01 \%), 250,81$ ha $(1,71 \%), 217,16$ ha $(1,48 \%)$, dan 338,92 ha $(2,31 \%)$. Peningkatan terbesar terjadi pada penggunaan lahan pertanian lahan kering campur sebesar $3,21 \%$ dan penurunan terbesar terjadi pada penggunaan lahan tanah terbuka sebesar 2,31\%.

Berdasarkan hasil analisis, peningkatan penggunaan lahan pertanian lahan kering dan permukiman merupakan konversi dari pertanian lahan kering campur, semak, dan tanah terbuka. Adanya perubahan pola penggunaan lahan menjadi permukiman memberi dampak terutama pada pengurangan kapasitas resapan sehingga aliran permukaan meningkat (Nugroho 2018). Selama periode 2012-2017, perubahan hutan lahan kering hanya sedikit sekali, yaitu sebesar $0,01 \%$. Hal ini dapat dinyatakan bahwa kontribusi hutan lahan kering dalam penambahan beberapa penggunaan lahan lainnya cukup kecil.

Secara umum, peningkatan penggunaan lahan pertanian lahan kering campur disertai dengan peningkatan penggunaan lahan permukiman. Peningkatan pertanian lahan kering campur sebagian besar merupakan konversi dari pertanian lahan kering, semak, dan tanah terbuka. Hal ini menunjukkan bahwa sebagian besar penduduk di daerah penelitian memenuhi kebutuhan hidupnya dari penggunaan lahan tersebut (Asdak 2010). Peningkatan luas permukiman sebagian besar berasal dari konversi semak belukar, tanah terbuka, dan sawah. Lahan semak dan sawah yang berpotensi terkonversi adalah yang letaknya dekat dengan permukiman. Peningkatan luas permukiman dapat dijadikan sebagai indikator peningkatan jumlah penduduk di suatu wilayah (Yusuf 2010).

\section{Hasil (Output) Simulasi Model SWAT}

Proses delineasi menghasilkan batas DAS, batas sub-DAS (subbasin), dan jaringan sungai. Delineasi dilakukan dengan ambang batas (threshold) sebesar 300 ha dengan tujuan agar mencakup seluruh jaringan sungai di Sub-DAS Opak Hulu. Hasil deliniasi model menghasilkan batas DAS dengan total luas 9537,32 ha dan dihasilkan sebanyak 9 sub-DAS. Peta sub-DAS hasil delineasi SWAT disajikan pada Gambar 3. Berdasarkan proses simulasi awal model SWAT sebelum dilakukan kalibrasi, dihasilkan nilai NSE sebesar 0,38 dan nilai koefisien determinasi $\left(R^{2}\right)$ sebesar 0,52.

\section{Kalibrasi dan Validasi Model SWAT}

Kalibrasi debit model dilakukan untuk membandingkan data debit hasil perhitungan model SWAT (berupa flow_out pada file rch) dengan debit observasi hasil pengukuran lapangan pada AWLR Pulo. Kalibrasi dilakukan berdasarkan data hasil hidrograf sebelumnya di mana nilai debit hasil simulasi tinggi pada beberapa titik dan rendah pada titik lainnya. Oleh karena itu, menurut Neitsch et al. (2001) perlu dilakukan penyesuaian parameter infiltrasi dan koefisien baseflow untuk meningkatkan nilai NSE dan $R^{2}$.

Hasil proses kalibrasi dengan membandingkan data debit observasi dengan debit simulasi model selama periode 1 tahun (1 Januari-31 Desember), yaitu pada tahun 2017 dihasilkan nilai NSE sebesar 0,72 (kategori baik) dan nilai koefisien determinasi $\left(R^{2}\right)$ sebesar 0,77 . Hidrograf perbandingan debit observasi dan debit simulasi hasil proses kalibrasi pada tahun 2017 disajikan pada Gambar 4. Nilai NSE $\geq 0,5$ dan $R^{2} \geq 0,6$

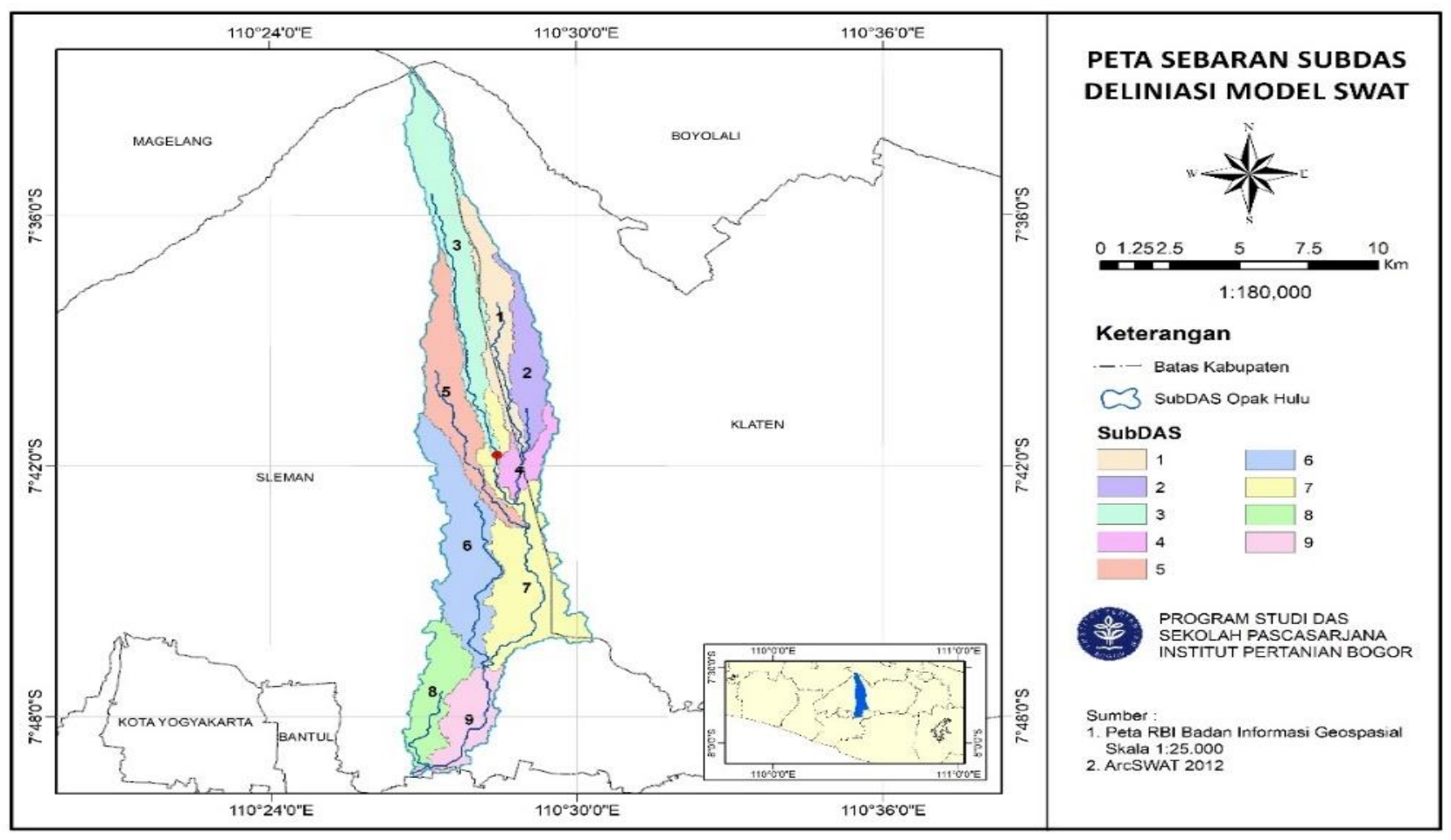

Gambar 3 Peta Sub-DAS hasil analisis SWAT Sub-DAS Opak Hulu. 
merupakan nilai yang dapat diterima (Santhi et al. 2001).

Validasi harian dilakukan selama periode 1 tahun (12 bulan), yaitu 1 Januari-31 Desember 2016 dengan parameter yang digunakan pada proses validasi sama dengan proses kalibrasi. Konsistensi model SWAT terlihat dari nilai NSE sebesar 0,68 (kategori baik) dan nilai koefisien determinasi $\left(R^{2}\right)$ sebesar 0,704 . Hidrograf perbandingan debit observasi dan debit simulasi hasil proses validasi pada tahun 2016 disajikan pada Gambar 5. Nilai kalibrasi dan validasi tersebut dapat diterima dan digunakan untuk proses analisis selanjutnya.

\section{Karakteristik Hidrologi Berdasarkan Simulasi} Model SWAT

- Neraca air

Persamaan neraca air dapat mensimulasikan proses hidrologi di suatu tempat pada periode tertentu. Air hujan yang jatuh dalam proses hidrologi dipetakan menjadi debit aliran, evapotranspirasi, dan simpanan air tanah. Debit aliran terdiri atas aliran permukaan, aliran lateral, dan aliran dasar. Neraca air hasil simulasi dari model SWAT pada periode 2016-2017 menunjukkan bahwa $65,82 \%$ dari total curah hujan $(2.572,3)$ menjadi aliran sungai atau streamflow, yaitu sebesar 1.693,01 mm. Menurut Arsyad (2010), aliran sungai berasal dari air hujan yang masuk ke dalam sungai dalam bentuk aliran permukaan, aliran lateral, air dasar, dan butir-butir hujan yang langsung jatuh ke permukaan sungai. Aliran sungai sebanyak $43,12 \%$ berasal dari aliran permukaan $(730,11 \mathrm{~mm})$ dan $56,88 \%$ berasal dari baseflow yang terdiri atas 272,14 $\mathrm{mm}$ aliran lateral (lateral flow) dan 690,76 mm aliran dasar (return flow).

Hasil analisis model SWAT mendeskripsikan bahwa $35,67 \%$ dari total curah hujan teruapkan kembali pada proses evapotranspirasi, yaitu sebesar 917,5 mm dengan ET potensial sebesar 2.029,6 mm. Air yang jatuh ke permukaan bumi masuk ke dalam tanah melalui proses infiltrasi, kemudian air yang masuk ke dalam tanah akan mengisi aquifer dangkal melalui

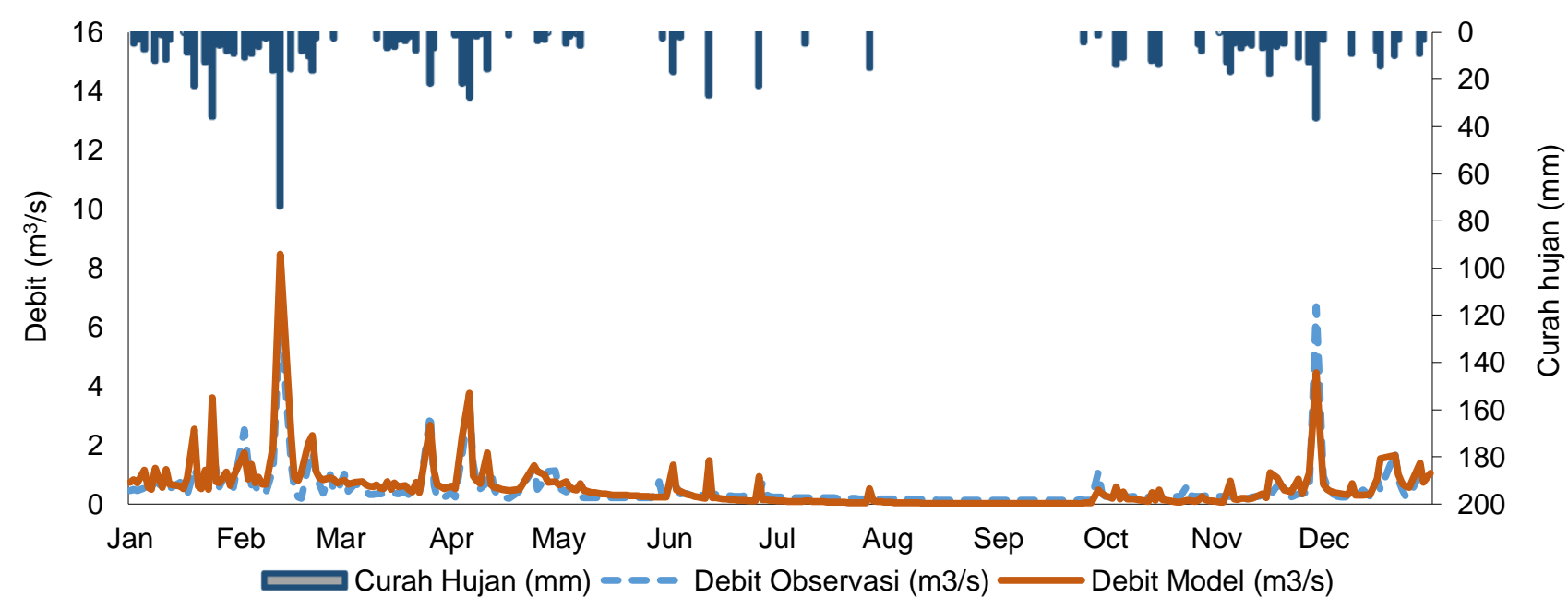

Gambar 4 Hidrograf debit observasi dan simulasi hasil kalibrasi tahun 2017.

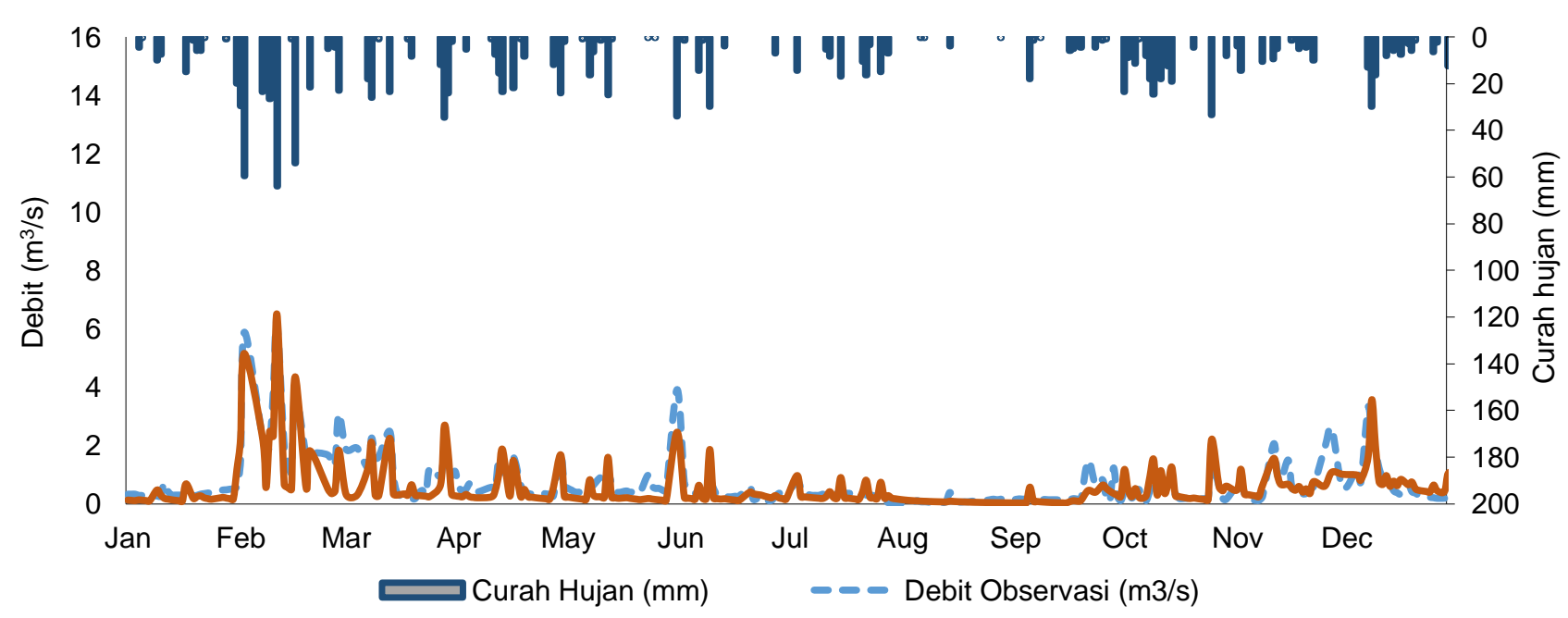

Gambar 5 Hidrograf debit observasi dan simulasi hasil kalibrasi tahun 2016. 
proses perkolasi sebesar $727,47 \mathrm{~mm} \mathrm{(28,28 \%}$ dari total curah hujan). Air yang mengisi aquifer dalam sebesar $36,37 \mathrm{~mm}(1,41 \%$ dari total curah hujan).

\section{Simulasi Penerapan Penggunaan Lahan Eksisting}

Penggunaan lahan yang digunakan pada kondisi existing adalah penggunaan lahan pada tahun 2017. Penggunaan lahan existing menunjukkan penggunaan lahan yang dominan di Sub-DAS Opak Hulu adalah permukiman seluas $3.053,30$ ha $(32,01 \%)$ dan sawah seluas $4.081,02$ ha $(42,79 \%)$, sedangkan luasan penggunaan lahan terkecil adalah semak belukar seluas 210,62 ha $(2,21 \%)$ dan hutan seluas 48 ha $(0,5 \%)$.

Hasil analisis model SWAT pada penerapan penggunaan lahan eksisting, dihasilkan curah hujan sebesar 2.546,69 $\mathrm{mm}$ dan total curah hujan yang menjadi aliran permukaan $719,04 \mathrm{~mm}$, aliran lateral sebesar $284,41 \mathrm{~mm}$, aliran dasar sebesar $637,82 \mathrm{~mm}$, dan hasil air sebesar $1.639,33 \mathrm{~mm}$. Nilai KAT yang dihasilkan sebesar 0,4 (kategori tinggi/T). Hal ini mengindikasikan bahwa curah hujan yang menjadi aliran langsung (direct runoff) cukup banyak. Aliran langsung ini merupakan penjumlahan dari aliran permukaan dan aliran lateral.

Debit tertinggi (Qmax) pada kondisi eksisting adalah sebesar 16,24 $\mathrm{m}^{3} /$ detik, sedangkan debit terendah (Qmin) adalah sebesar 0,191 $\mathrm{m}^{3} /$ detik, sehingga diperoleh nilai KRA sebesar 85,16 yang termasuk golongan tinggi $(80<\mathrm{KRA}<110)$. Fluktuasi debit aliran sungai dipengaruhi oleh ragam curah hujan, pengelolaan lahan pertanian tanpa menerapkan teknik KTA, dan pemanfaatan penggunaan lahan yang tidak sesuai dengan kapasitas daya dukungnya (Hidayat et al. 2013).

\section{- Skenario 1: penerapan RTk-RHL BPDAS SOP}

Simulasi model Skenario 1 merupakan penerapan peta penggunaan lahan sesuai dengan peta Rencana Teknik Rehabilitasi Hutan dan Lahan Daerah Aliran Sungai (RTk-RHL DAS) Tahun 2015-2029 (BPDAS Serayu Opak Progo 2014).

Penggunaan lahan yang mendominasi penerapan Skenario 1 adalah sawah seluas 3.989 ha $(41,84 \%)$ dan luasan yang paling kecil adalah tanah terbuka seluas 2,27 ha $(0,02 \%)$. Kegiatan RHL pada sub-das yang termasuk ke dalam kawasan hutan adalah reboisasi. Rehabilitasi pada sub-das yang berada di luar kawasan hutan berupa agroforestry dan hutan rakyat (vegetasi jarang dan lahan terbuka). Pada areal pertanian lahan kering, pertanian lahan kering campur, dan tanah terbuka yang berada di luar kawasan hutan dengan kemiringan lahan $15-40 \%$ dilakukan rehabilitasi secara sipil teknis berupa teras gulud, gully plug, dan saluran pembuangan air.

Penerapan penggunaan lahan pada Skenario 1 menghasilkan aliran permukaan sebesar $675,78 \mathrm{~mm}$ atau menurun dari kondisi existing. Kegiatan $\mathrm{RHL}$ tersebut diterapkan melalui kegiatan reboisasi seluas 378,57 ha, agroforestri seluas $1.132,32$, dan peng- hijauan dalam kawasan hutan sebesar 389,23 ha. Aliran lateral yang dihasilkan sebesar $378,57 \mathrm{~mm}$, aliran dasar sebesar $696,26 \mathrm{~mm}$, dan hasil air sebesar $1.635,9 \mathrm{~mm}$. Nilai KAT yang dihasilkan dari Skenario 1 adalah sebesar 0,38 dengan kategori sedang (S).

Skenario RTk-RHL menghasilkan debit tertinggi (Qmax) sebesar 15,07 m/detik, sedangkan debit terendah (Qmin) adalah sebesar 0,195 $\mathrm{m}^{3} /$ detik sehingga diperoleh nilai KRS sebesar 77,12 yang termasuk golongan sedang $(50<\mathrm{KRA}<80)$.

\section{- Skenario 2: penerapan RTRW Provinsi DIY dan Jawa Tengah}

Simulasi model Skenario 2 adalah penerapan peta penggunaan lahan sesuai dengan Rencana Tata Ruang Wilayah (RTRW) Provinsi D.I.Yogyakarta dan Jawa Tengah tahun 2012-2032. Beberapa penggunaan lahan yang terdapat dalam rekomendasi peta RTRW ini antara lain adalah kawasan hutan rakyat, kawasan industri, peruntukan hortikultura, peruntukan permukiman, peruntukan pertanian tanaman pangan, dan taman nasional gunung merapi.

Penggunaan lahan yang mendominasi dalam penerapan RTRW ini adalah kawasan peruntukan pertanian tanaman pangan seluas 3.061 ha $(32,10 \%)$ dan peruntukan permukiman seluas 2.035 ha $(21,34 \%)$. Luasan yang paling kecil adalah tanah terbuka seluas 12 ha $(0,13 \%)$.

Penerapan penggunaan lahan pada Skenario 2 menghasilkan aliran permukaan sebesar $655,05 \mathrm{~mm}$ atau berkurang dibandingkan dengan kondisi existing. Sementara itu, aliran lateral sebesar $302,92 \mathrm{~mm}$ dan aliran dasar sebesar $731,45 \mathrm{~mm}$ atau bertambah dibandingkan dengan kondisi existing, serta hasil air sebesar 1.650,71 mm. Adanya pengurangan aliran permukaan serta penambahan aliran lateral dan aliran dasar dikarenakan adanya kawasan resapan air yang didefinisikan sebagai kawasan hutan rakyat. Nilai KAT yang dihasilkan dari Skenario 2 adalah sebesar 0,37 dengan kategori sedang (S).

Skenario penerapan RT/RW menghasilkan debit tertinggi (Qmax) sebesar 15,39 $\mathrm{m}^{3} /$ detik, sedangkan debit terendah (Qmin) sebesar 0,195 $\mathrm{m}^{3} /$ detik sehingga diperoleh nilai KRA sebesar 78,76 yang termasuk golongan sedang $(50<\mathrm{KRA}<80)$.

\section{- Skenario 3: penerapan penggunaan lahan eksisting dengan teknik KTA}

Simulasi model Skenario 3 merupakan penerapan peta penggunaan lahan eksisting yang dikombinasikan dengan teknik konservasi tanah dan air (KTA), yaitu agroforestry, countouring, reboisasi, dan sumur resapan. Parameter dalam model SWAT yang diaplikasikan adalah CN2 (bilangan kurva aliran permukaan). Penerapan teknik KTA ini difokuskan pada sub-DAS yang dianggap bermasalah, yaitu sub-DAS yang memiliki nilai KAT dengan kategori sangat tinggi (ST) dan tinggi (T) pada penerapan penggunaan lahan eksisting. Penerapan teknik KTA pada Skenario 3 disampaikan pada Tabel 5. 
Penerapan teknik Konservasi Tanah dan Air (KTA) penggunaan lahan pertanian lahan kering dan pertanian lahan kering campur berupa agroforestry pada kemiringan lereng $25-40 \%$ adalah seluas 90,62 ha. Teknik KTA contouring diterapkan pada penggunaan lahan pertanian lahan kering, pertanian lahan kering campur, semak belukar, dan tanah terbuka sebesar 716,21 ha pada kemiringan lereng $8-25 \%$. Reboisasi diterapkan pada lereng $>40 \%$, yaitu penggunaan lahan hutan lahan kering sekunder, hutan tanaman, dan tanah terbuka sebesar 878,11 ha yang berada pada hulu Sub-DAS Opak Hulu. Teknik KTA mekanik sumur resapan diterapkan pada penggunaan lahan permukiman pada lereng $0-25 \%$ sebesar $3.047,85$ ha yang berada pada bagian tengah maupun hilir sub-DAS.

Penerapan teknik KTA pada penggunaan lahan eksisting (Skenario 3) menghasilkan aliran permukaan sebesar $524,22 \mathrm{~mm}$, aliran lateral sebesar $321,82 \mathrm{~mm}$, aliran dasar sebesar $797,28 \mathrm{~mm}$, dan hasil air sebesar $1.622,02 \mathrm{~mm}$. Sebagian besar penerapan skenario teknik KTA menurunkan aliran permukaan dan meningkatkan aliran lateral, aliran dasar, serta hasil air.

Nilai KAT yang dihasilkan dari penerapan Skenario 3 adalah 0,33 dengan kategori sedang (S). Skenario penerapan teknik KTA menghasilkan debit tertinggi (Qmax) sebesar 14,78 $\mathrm{m}^{3} /$ detik, sedangkan debit terendah (Qmin) sebesar 0,21 $\mathrm{m}^{3} /$ detik sehingga diperoleh nilai KRA sebesar 69,85 yang termasuk golongan sedang $(50<\mathrm{KRA}<80)$.

\section{Perencanaan Pengelolaan DAS Terbaik}

Hasil simulasi SWAT pada kondisi penggunaan lahan existing pada tahun 2017 serta penerapan
Skenario 1, 2, dan 3 menunjukkan hasil karakteristik hidrologi yang berbeda. Penerapan Skenario 1, 2, 3, yaitu RTk-RHL, RTRW, dan teknik KAT merupakan skenario yang baik dalam perencanaan pengelolaan Sub-DAS Opak hulu karena mampu menurunkan aliran permukaan, meningkatkan aliran lateral, dan aliran dasar. Pada kondisi eksisting, aliran permukaan yang dihasilkan adalah sebesar 719,04 mm, aliran lateral sebesar $284,41 \mathrm{~mm}$, aliran dasar sebesar $673,82 \mathrm{~mm}$, dan hasil air sebesar $1.639,33 \mathrm{~mm}$. Penerapan Skenario 1 (RTk-RHL) menurunkan aliran permukaan sebesar $675,78 \mathrm{~mm}(6,02 \%)$, meningkatkan aliran lateral sebesar $298,27 \mathrm{~mm}(4,87 \%)$ dan aliran dasar sebesar $696,26 \mathrm{~mm}(3,33 \%)$, serta hasil air sebesar $1.635,9 \mathrm{~mm}$. Penerapan Skenario 2 (RTRW) mampu menurunkan aliran permukaan sebesar 655,05 $\mathrm{mm}(8,9 \%)$, meningkatkan aliran lateral sebesar $302,92 \mathrm{~mm}(6,51 \%)$ dan aliran dasar sebesar $731,45 \mathrm{~mm}(8,28 \%)$, serta hasil air $1.650,71$ $\mathrm{mm}$. Penerapan Skenario 3 (Teknik KTA), menurunkan aliran permukaan sebesar 524,22 $\mathrm{mm}(27,09 \%)$, meningkatkan aliran lateral sebesar $321,82 \mathrm{~mm}$ $(13,15 \%)$, dan aliran dasar sebesar 797,28 mm $(18,32 \%)$, serta hasil air sebesar $1.622,02 \mathrm{~mm}$. Rekapitulasi perubahan karakteristik hidrologi pada simulasi berbagai skenario (Eksisting, 1, 2, dan 3) berdasarkan nilai curah hujan, aliran permukaan, aliran dasar, dan total hasil air disajikan pada Tabel 6 .

Berdasarkan Tabel 7 , nilai KAT yang dihasilkan oleh kondisi eksisting adalah sebesar 0,4 yang masuk ke dalam kategori tinggi $(T)$ dan nilai KRA menunjukkan nilai 85,16 yang termasuk ke dalam kategori tinggi $(\mathrm{T})$ dengan debit maksimum sebesar 16,24 $\mathrm{m}^{3} /$ detik dan debit minimum sebesar $0,191 \mathrm{~m}^{3} /$ detik.

Tabel 5 Penerapan teknik koefisien aliran tahunan (KTA) Skenario 3

\begin{tabular}{lcrr}
\hline \multicolumn{1}{c}{ Penerapan KTA } & Lereng (\%) & Penggunaan lahan & Luas (ha) \\
\hline Agroforestry & $25-40$ & PLKC danPLKR & 90,62 \\
Countouring & $8-25$ & PLKC, PLKR, BLKR, dan TBKA & 716,21 \\
Reboisasi & $>40$ & HLKS, HUTN, dan TBKA & 878,11 \\
Sumur Resapan & $0-25$ & PMKN & 3047,85 \\
\hline
\end{tabular}

Keterangan: $\quad$ PLKR $=$ Pertanian lahan kering, $\mathrm{PLKC}=$ Pertanian lahan kering campur, BLKR $=$ Semak/belukar, HLKS $=$ Hutan lahan kering sekunder, HTNM = Hutan tanaman, TBKA = Tanah terbuka, PMKN = Permukiman, dan SWAH = Sawah.

Tabel 6 Karakteristik hidrologi Sub-DAS Opak Hulu hasil simulasi berbagai skenario

\begin{tabular}{|c|c|c|c|c|c|c|c|}
\hline \multirow{2}{*}{ Karakteristik hidrologi } & Eksisting & \multicolumn{2}{|c|}{ Skenario 1} & \multicolumn{2}{|c|}{ Skenario 2} & \multicolumn{2}{|c|}{ Skenario 3} \\
\hline & $(\mathrm{mm})$ & $(\mathrm{mm})$ & $\Delta(\%)$ & $(\mathrm{mm})$ & $\Delta(\%)$ & $(\mathrm{mm})$ & $\Delta(\%)$ \\
\hline Curah hujan & $2.546,69$ & $2.546,69$ & & $2.546,69$ & & $2.546,69$ & \\
\hline Aliran permukaan & 719,04 & 675,78 & $-6,02$ & 655,05 & $-8,90$ & 524,22 & $-27,09$ \\
\hline Aliran lateral & 284,41 & 298,27 & 4,87 & 302,92 & 6,51 & 321,82 & 13,15 \\
\hline Aliran dasar & 673,82 & 696,26 & 3,33 & 731,45 & 8,28 & 797,28 & 18,32 \\
\hline Total hasil air & $1.639,33$ & $1.635,90$ & & $1.650,71$ & & $1.622,02$ & \\
\hline
\end{tabular}

Tabel 7 Nilai koefisien aliran tahunan (KAT) dan koefisien regim aliran (KRA) pada berbagai penerapan skenario

\begin{tabular}{llcrrrr}
\hline \multicolumn{1}{c}{ Skenario } & $\mathrm{CH}(\mathrm{mm})$ & $\mathrm{DRO}(\mathrm{mm})$ & $\mathrm{KAT}$ & $\mathrm{Qmax}\left(\mathrm{m}^{3} / \mathrm{s}\right)$ & $\mathrm{Qmin}\left(\mathrm{m}^{3} / \mathrm{s}\right)$ & $\mathrm{KRA}$ \\
\hline Eksisting & $2.546,69$ & $1.003,45$ & $0,4(\mathrm{~T})$ & 16,24 & 0,191 & $85,16(\mathrm{~T})$ \\
RTk-RHL & $2.546,69$ & 974,05 & $0,38(\mathrm{~S})$ & 15,07 & 0,195 & $77,12(\mathrm{~S})$ \\
RTRW & $2.546,69$ & 957,97 & $0,37(\mathrm{~S})$ & 15,39 & 0,195 & $78,76(\mathrm{~S})$ \\
Teknik KTA & $2.546,69$ & 846,04 & $0,33(\mathrm{~S})$ & 14,78 & 0,212 & $69,85(\mathrm{~S})$ \\
\hline
\end{tabular}


Nilai KAT yang dihasilkan dengan penerapan Skenario 1 (RTk-RHL) adalah sebesar 0,38 yang masuk ke dalam kategori sedang (S) dan nilai KRA menunjukkan nilai sebesar 77,12 yang masuk ke dalam kategori sedang (S) dengan debit maksimum sebesar 15,07 $\mathrm{m}^{3} /$ detik dan debit minimum sebesar 0,195 $\mathrm{m}^{3} /$ detik. Nilai KAT yang dihasilkan dengan penerapan Skenario 2 (RTRW) adalah sebesar 0,37 yang masuk ke dalam kategori sedang (S) dan nilai KRA menunjukkan nilai 78,76 yang masuk ke dalam kategori sedang (S) dengan debit maksimum sebesar 15,39 $\mathrm{m}^{3} /$ detik dan debit minimum sebesar $0,195 \mathrm{~m}^{3} /$ detik. Nilai KAT yang dihasilkan dengan penerapan Skenario 3 (Teknik KTA) adalah sebesar 0,33 yang masuk ke dalam kategori sedang (S) dan nilai KRA menunjukkan nilai sebesar 69,85 yang masuk ke dalam kategori sedang (S) dengan debit maksimum sebesar 14,78 $\mathrm{m}^{3} /$ detik dan debit minimum sebesar 0,212 $\mathrm{m}^{3} /$ detik. Adanya penurunan aliran permukaan serta penambahan aliran lateral dan aliran dasar yang berpengaruh pada nilai KAT dan KRA yang semakin berkurang dikarenakan adanya penerapan teknik KTA seperti agroforestry, reboisasi, contouring, dan sumur resapan pada penggunaan lahan tertentu serta pada sub-DAS tertentu.

Rekapitulasi hasil karakteristik hidrologi yang telah disajikan dari beberapa penerapan skenario serta nilai KAT dan KRA, dapat dinyatakan bahwa Skenario 3 (Teknik KTA) merupakan skenario yang paling terbaik untuk pengelolaan di Sub-DAS Opak Hulu. Penggunaan lahan permukiman yang nilai aliran permukaannya tinggi diterapkan teknik KTA berupa sumur resapan. Menurut Tarigan (2016), sumur resapan mampu mengurangi 0,7 air limpasan dan sebanyak 0,3 berpotensi menjadi air limpasan sehingga nilai $\mathrm{CN}$ berkurang. Konservasi sumber daya air berupa simulasi sumur resapan pada permukiman memperlihatkan penurunan nilai kurva limpasan (CN) sebesar 0,35 (Rahardian \& Buchori 2016). Simulasi konservasi menggunakan sumur resapan dengan asumsi mampu meningkatkan kapasitas infiltrasi sebesar $50 \%$ pada permukiman menunjukkan adanya penurunan nilai Koefisien Rejim Sungai (KRS), di mana semakin tinggi nilai limpasan maka jumlah sumur resapan yang diperlukan akan semakin banyak (Hendriyanto et al. 2019). Berdasarkan hasil simulasi SWAT pada penerapan Iahan permukiman Sub-DAS Opak Hulu, seluas $3.047,85$ ha atau $31,96 \%$ dari total luas DAS dibutuhkan sumur resapan sebanyak 106.675 unit sehingga dapat menurunkan aliran permukaan.

Penerapan teknik KTA agroforestri pada pertanian lahan kering dan lahan kering campur berupa tanaman tertentu, seperti jati, mahoni, sirsak, nangka, sukun, maupun rambutan mampu menurunkan aliran permukaan. Perubahan penutupan lahan dari pertanian lahan kering campur dan hutan lahan kering sekunder menjadi agroforestri, serta perbaikan drainase pada permukiman dengan sumur resapan mampu mengubah nilai $\mathrm{CN}$ dan menurunkan aliran permukaan yang lebih kecil dengan input curah hujan yang sama (Laturua et al. 2018).

Penerapan Skenario 3 menurunkan aliran permukaan, menaikkan aliran lateral dan aliran dasar, sehingga nilai KAT menjadi kategori rendah. Selain itu juga, nisbah antara nilai debit maksimum dan debit minimum semakin kecil. Semakin kecil nisbah debit maksimum dan debit minimum (KRA) menggambarkan adanya keberlangsungan aliran, artinya tidak terjadi kekeringan pada musim kemarau dan debit maksimum yang dihasilkan dapat dikendalikan sehingga kemungkinan terjadinya banjir dapat dikurangi. Teknik konservasi tanah teras, penanaman menurut kontur, penanaman strip (stripcropping), dan agroforestri dapat menghambat aliran permukaan (Yustika 2012). Berdasarkan nilai KAT dan KRA dari penerapan Skenario 3 dapat dikatakan fungsi hidrologis sub-DAS Opak Hulu semakin membaik.

\section{KESIMPULAN}

Model hidrologi SWAT dapat memprediksi dan mensimulasikan debit aliran di Sub-DAS Opak Hulu dengan baik (NSE 0,72 dan $R^{2} 0,77$ ). Penggunaan lahan pada periode tahun 2012-2017 di Sub-DAS Opak Hulu mengalami perubahan, yaitu pada pertanian lahan kering campur dan semak belukar mengalami peningkatan signifikan, sedangkan penggunaan lahan yang banyak mengalami penurunan luasan secara signifikan adalah pada lahan pertanian lahan kering dan tanah terbuka. Perubahan penggunaan lahan membawa pengaruh pada respons hidrologi Sub-DAS Opak Hulu periode pada tahun 2012-2017, nilai KAT pada lahan eksisting adalah sebesar 0,40 yang masuk ke dalam kategori tinggi ( $T$ ) dan KRA adalah sebesar 85,16 yang masuk dalam kategori tinggi (T). Berdasarkan hasil analisis respons hidrologi dapat disimpulkan bahwa semua penerapan skenario dapat menurunkan aliran permukaan, meningkatkan aliran lateral dan aliran dasar, menurunkan debit maksimum, serta meningkatkan debit minimum, sehingga dapat dinyatakan bahwa fungsi hidrologis DAS mulai membaik dengan penurunan nilai KRA dan KAT. Namun demikian, skenario teknik KTA metode vegetatif agroforestry dengan tanaman tertentu, seperti jati, mahoni, sirsat, nangka, sukun, maupun rambutan diterapkan pada lahan pertanian. Pada lahan permukiman dapat diterapkan sumur resapan atau biopori, serta reboisasi pada lereng $>40 \%$ direkomendasikan dalam perencanaan pengelolaan Sub-DAS Opak Hulu untuk meningkatkan fungsi hidrologis DAS secara optimal.

\section{UCAPAN TERIMA KASIH}

Diucapkan terima kasih kepada pembimbing dan Ketua Program Studi IImu Pengelolaan DAS IPB, Balai 
Besar Wilayah Sungai Serayu Opak (BBWS SO) dan Balai Pengelolaan Daerah Aliran Sungai dan Hutan Lindung Serayu Opak Progo (BPDAS-HL SOP) yang telah memberikan fasilitas dalam pelaksanaan penelitian.

\section{DAFTAR PUSTAKA}

Arnold JG, Kiniry JR, Srinivasan R, Williams JR, Haney EB, Neitsch SL. 2011. Soil and Water Assessment Tool Input/Output File Documentation Version 2009. Agricultural Research Service and Texas AgriLife Research. College Station

Arnold JG, Kiniry JR, Srinivasan R, Williams JR, Haney EB, Neitsch SL. 2012. Soil and Water Assessment Tool: Input/Output File Documentation Version 2009. College of Agricultire and Life Science Texas A\&M University. Texas.

Arsyad S. 2010. Konservasi Tanah dan Air. Edisi ke-2. Bogor (ID): IPB Press.

[BBWS SO]. Balai Besar Wilayah Sungai Serayu Opak. 2010. Pola Pengelolaan Sumber Daya Air Wilayah Sungai Progo Opak Serang. Keputusan Menteri Pekerjaan Umum. No 590/KPTS/M/2010.

[BPDAS SOP]. Balai Pengelola Daerah Aliran Sungai. 2014. Laporan Kinerja BPDAS Serayu Opak Progo Tahun 2014.

[BPDAS-HL SOP]. Balai Pengelola Daerah Aliran Sungai dan Hutan Lindung. 2016. Laporan Kinerja BPDAS-HL Serayu Opak Progo Tahun 2016.

[BPDAS-HL SOP]. Balai Pengelola Daerah Aliran Sungai dan Hutan Lindung. 2018. Laporan Kinerja BPDAS-HL Serayu Opak Progo Tahun 2018.

[BPS]. Badan Pusat Statistik. 2019. Pertumbuhan Penduduk DIY. Yogyakarta (ID).

Chaube UC, Suryavanshi S, Nurzaman L, Pandey A. 2011. Synthesis of flow series of tributaries in upper Betwa basin. International Journal of Environmental Science. 1(7). 1459-1475

Hendriyanto HS, Purwanto YJ, Setiawan Y. 2019. Penggunaan Tank Model untuk Mempelajari Tindakan Konservasi Tanah dan Hubungannya dengan Debit Sungai di Sub DAS Ciliwung HuluCiliwung. Jurnal Keteknikan Pertanian. 7(1):1-8.

Hidayat Y, Murtilaksono K, Wahyunie ED, Panuju RD. 2013. Pencirian debit aliran sungai Citarum Hulu. Jurnal IImu Pertanian Indonesia. 18(2): 109-114.

Junaidi E, Tarigan SD. 2012. Penggunaan Model Hidrologi SWAT (Soil and Water Assessment Tool) dalam Pengelolaan DAS Cisadane. Jurnal Penelitian Hutan dan Konservasi Alam. 9(3): 221-237. https://doi.org/10.20886/jphka.2012. 9.3.221-237
Laturuan A, Hendrayanto, Puspaningsih N. 2018. Penggunaan Lahan Optimal dalam Transformasi Hujan Limpasan di DAS Wae Ruhu. Media Konservasi. 23(1): 52-64.

Manan S. 1979. Pengaruh Hutan dan Manajemen Daerah Aliran Sungai. Bogor (ID): Institut Pertanian Bogor.

Moriasi DN, Arnold JG, Liew MWV, Bingner RL, Harmel RD, Veith TL. 2007. Model evaluation guidelines for systematic quantification of accuracy in watershed simulations. Journal American Society of Agricultural and Biological Engineers. 50(3): 885-900.

Neitsch SL, Arnold JG, Kiniry JR, Williams JR. 2005. Soil and Water Assessment Tool : Theoritical Documentation Version 2005. Agricultural Research Service and Texas Agricultural Experiment Station. Temple

Neitsch SL, Arnold JG, Kiniry JR, Williams JR. 2001a. Soil and Water Assessment Tool; Theoretical Documentation Version 2000. Soil and Water Research Laboratory-ARS. Texas.

Nugroho SP. 2000. Analisis Aliran Permukaan, Sedimen, dan Hara Nitrogen, Fosfor, dan Kebutuhan Oksigen Kimiawi Dengan Menggunakan Model AGNPS di Sub DAS Dumpul. [tesis]. Bogor (ID): Program Pasca Sarjana. Institut Pertanian Bogor.

Nugroho SP. 2018. Analisis Perubahan Penggunaan Lahan dan Debit Aliran di Sub DAS Citatih. Jurnal Pengelolaan Sumberdaya Alam dan Lingkungan. 8(2): 258-263. https://doi.org/10.29244/jpsl. 8.2.258-263

Nuryanto A, Setyawati D, Lidiawati I, Suyana J, Karlinasari L, Nasri MA, Puspaningsih N, Yuwono SB. 2003. Strategi Pengelolaan DAS dalam Rangka Optimalisasi Kelestarian Sumber Daya Air: Studi Kasus DAS Ciliwung Hulu. Makalah Pengantar Falsafah Sains. Bogor (ID): Institut Pertanian Bogor.

Pawitan H. 2006. Perubahan Penggunaan Lahan dan Pengaruhnya terhadap Hidrologi DAS. Bogor (ID): Laboratorium Hidrometeorologi FMIPA, IPB. 2008. Analisis Sistem Hidrologi. Bahan Kuliah. Bogor (ID): Program Pascasarjana, Institut Pertanian Bogor.

Rachman A, Dariah A. 2007. Pemodelan dalam Perencanaan Konservasi Tanah Air. Di dalam : Prosiding Seminar dan Kongres Nasional VI MKTI; Cisarua, 17-18 Des 2007. Bogor (ID): Perhimpunan MKTI.

Rahadian A, Buchori I. 2016. Dampak Perubahan Penggunaan Lahan Terhadap Limpasan Permukaan dan Laju Aliran Puncak Sub DAS Gajahwong Hulu-Kabupaten Sleman. Jurnal Pembangunan Wilayah dan Kota. 12(2):127-139. https://doi.org/10.14710/pwk.v12i2.12890 
Santhi C, Srinivasan R, Arnold JG, Williams JR. 2001. Validation of The SWAT Model on a Large River Basin with Point and Nonpoint Sources. Jawra Journal of the American Water Resources Association. 37(5): 1169-1188.

Silva GM, Netto AAO, Neves JJR, Vasco NA, Ahmeida C, Faccioli GG. 2015. Sensitivity analysis and calibration of hydrological modeling of the watershed Northeast Brazil. Journal of Environmental Protection. 6: 837-850.

Sudadi UDPT, Baskoro, Munibah K, Barus B, Darmawan. 1991. Kajian pengaruh perubahan penggunaan lahan terhadap aliran sungai dan penurunan kualitas lahan di sub DAS Ciliwung Hulu dengan pendekatan model simulasi hidrologi. Laporan Penelitian. Bogor (ID): Institut Pertanian Bogor

Tarigan SD. 2016. Tarigan SD. 2016. Modelling effectiveness of management practices for flood mitigation using GIS spatial analysis functions in Upper Ciliwung watershed. Earth and
Environmental Science. 31(2016): 012030. https://doi.org/10.1088/1755-1315/31/1/012030

Elsevier Procedia Environmental Sciences 33, pp 386392.

Vink APA. 1975. Land Use in Advancing Agriculture. New York (US): Springer-Verlag. https://doi.org/ 10.1007/978-3-642-66049-8

Wang X, Kannan N, Santhi C, Potter SR, Williams JR, and Arnold JG. 2011. Integrating APEX output for cultivated cropland with SWAT simulation for regional modeling. Journal American Society of Agricultural and Biological Engineers. 54(4): 1281-1298.

Yustika RD. 2012. Simulasi Manajemen Lahan di DAS Ciliwung Hulu Menggunakan Model SWAT. Jurnal Informatika Pertanian. 21(2): 71-79. https://doi.org/ 10.21082/ip.v21n2.2012.p71-79

Yusuf SM. 2010. Kajian respons perubahan penggunaan lahan terhadap karakteristik hidrologi di DAS Cirasea menggunakan model MWSWAT [tesis]. Bogor (ID): Institut Pertanian Bogor. 